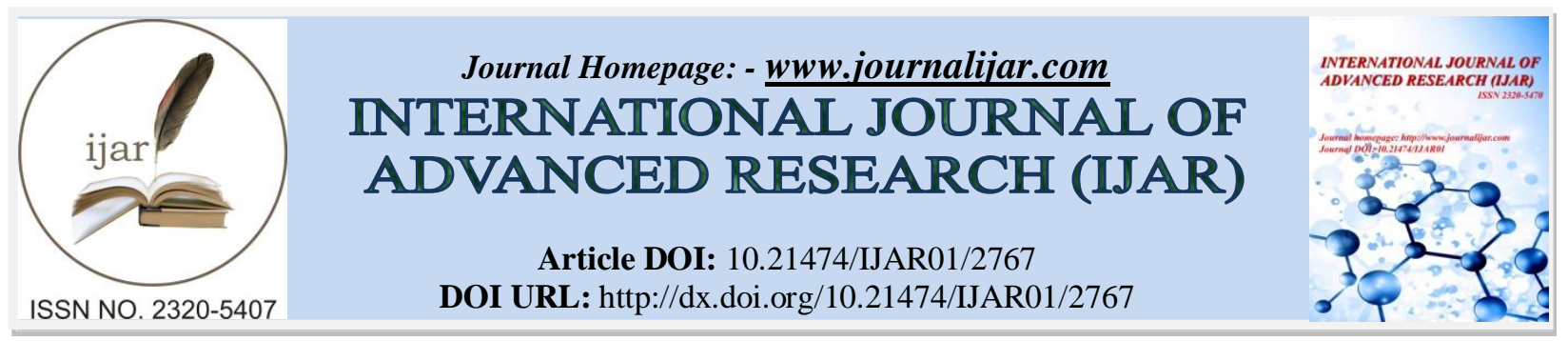

RESEARCH ARTICLE

\title{
A Study on Phytodiversity in Flouride contaminated site near Coromandel area in Visakhapatnam.
}

CH. Sri Bindu ${ }^{1}$, Dr. J. Ratna Grace ${ }^{2}$, Prabhavati Devi ${ }^{3}$ and Dr. Y. Venkateswara Rao ${ }^{4}$.

1. Research scholar, Centre for Research, Dr.V.S.Krishna Govt. Degree \& PG College (A); Maddilapalem

2. Reader, Coordinator PG Botany \& Biotechnology Dr.V.S.Krishna Govt. Degree \& PG College (A); Maddilapalem, Visakhapatnam.

3. Research scholar, Department of Analytical chemistry, Andhra University, Visakhapatnam.

4. Professor, Head of the Department of Botany, Andhra University, and Visakhapatnam.

\section{Manuscript Info}

\section{Manuscript History}

Received: 15 November 2016

Final Accepted: 17 December 2016

Published: January 2017

\section{Key words:-}

Fluoride aaccumulation, phytodiversity, IVI, phytoremediation.

\section{Abstract}

Increased population, industrialization and urbanization are responsible for environmental ccontamination. The discharge of industrial waste water, without any prior treatment in to the environment has always affected the health of human beings, plants and animals. These effluents contain toxic chemicals which are not degradable via chemical and microbial processes. However, they are very likely to accumulate in the soil, aquatic environment and in the plant organs. 2. In this genomic era development of science and technology facilitates the use of the potential of biological diversity for pollution removal which is termed as Bioremediation. 3. In any bioremediation study, site characterization is the preliminary step and is very important with respect to future application or augmentation of the organisms into the particular site involved. 4 . In view of this the present study was undertaken to characterize the phytodiversity in fluoride contaminated site near Coromandel area in Visakhapatnam for their possible use in phytoremediation.

Copy Right, IJAR, 2016,. All rights reserved.

\section{Introduction:-}

The problem of environmental pollution has existed since early time and is still growing rapidly as a result of industrialization in developing countries like India (Naheed et .al, 1986). Industrial pollution is caused by discharge of various chemicals in the form of gases, liquids, and solids which affects the physical, chemical and biological conditions of the environment and is harmful to all living beings (Dueck and Endenjik, 1987). Various industrial pollutants affecting the plants have been reported which include many metalloids, heavy metals and other phenol's etc.

Metals in general are a class of chemical compounds that are good conductors of heat and electricity (Ghosh and Singh 2005). From past 10 to 15 years the disturbance caused by these metals to the nature has been of great concern. Among such metals, special attention is drawn with reference to fluoride which is a strong electronegative element wide spread in the environment (Jha et al.2009), Chemically active in nature and found mostly in combination with other metals like cadmium, zinc etc. Fluoride is a serious contaminant, even present at low levels as it can persist for a long time in the environment and exert negative effects at all levels of an ecosystem (Ares. $\mathrm{J}$ .O. Villa and Mandodari 1980). 
The exact mechanism by which fluoride causes damage to plants is little understood. Nevertheless, certain physiological processes are known to be markedly affected by fluoride. For example, a decrease in chlorophyll (McNulty \& Newman, 1961), a diminished rate of photosynthesis (Thomas \& Hendricks, 1956), decreased plant growth (Bonner \& Thimann, 1950) and increased respiration in growing plants (McNulty \& Newman, 1957) have been reported. An effect of fluoride on a physiological process may be a reflection that one or more enzyme systems are affected by fluoride.

The determination of fluoride contamination has received extensive attention because of its significant effects in plants and animals. The number of articles published on determination of fluoride has increased significantly in the recent years. Numerous methods have been developed to determine the amount of fluoride in various samples, which include, electrochemical methods (potentiometry, voltammetry) Chromatography, Sensors, Micro fluidic analysis, Titration and spectroscopy. Among them, Potentiometric determination by F-ISE (ion selective electrode) is the widely used method (Borjigin et al 2009, Krishna et al 2012).

\section{Need for remediation:-}

The use of biological diversity for the removal of chemicals in soil and water called bioremediation which is the emerging, efficient and innovative tool for management of a wide array of contaminants. This technology includes phytoremediation ( use of plants), microbial remediation (use of microbes) and rhizo remediation (plant and microbe interaction)among which phyto remediation is the most evolved one, which is applicable for removal of contaminants in soil, surface water, ground water and sediments in air(Bindu Madhavi and Gaurav Reddy2014.).

The present study was undertaken with the objectives of investigating the phyto diversity of area adjacent to the Coromandel Fertilizer limited that has high fluoride content and also to study the quantitative charecters of the plant species so as to identify the abundantly growing plant species which may be the possible fluoride tolerant species that can be used to phytoremediate the flouride contaminated sites.

\section{Study area:-}

Visakhapatnam is located on the east coast of India on $17^{0}-43^{\prime} \mathrm{N}$ latitude $83^{\circ}-17^{\prime} \mathrm{S}$ longitude and in between Calcutta and Madras. The surroundings of Visakhapatnam are rich in natural flora and approx. 550 species belonging to many Angiosperm families (Venkateswarulu J. Bhirava murthy and P. Narasimha Rao 1972 ). Vishakhapatnam is surrounded by many industries which discharge their effluents containing chemical pollutants in to the environment. Among them Coromandel Fertilizer Limited(fig 1,2) is the major one, which is spread over an area of about 480 acres of land at sriharipuram lying to south of Visakhapatnam. A vast stretch of barren and vacant land remained adjacent to the industry where the effluents (raw material containing fluoride) released from the industry are flowing through a narrow stream into the surrounding area. The effluent affected area is occupied by herbaceous vegetation(fig3), with a limited number of species. Few of them are capable of accumulating high amounts of fluoride in their tissues (P.V. Arjun Rao,1992) 

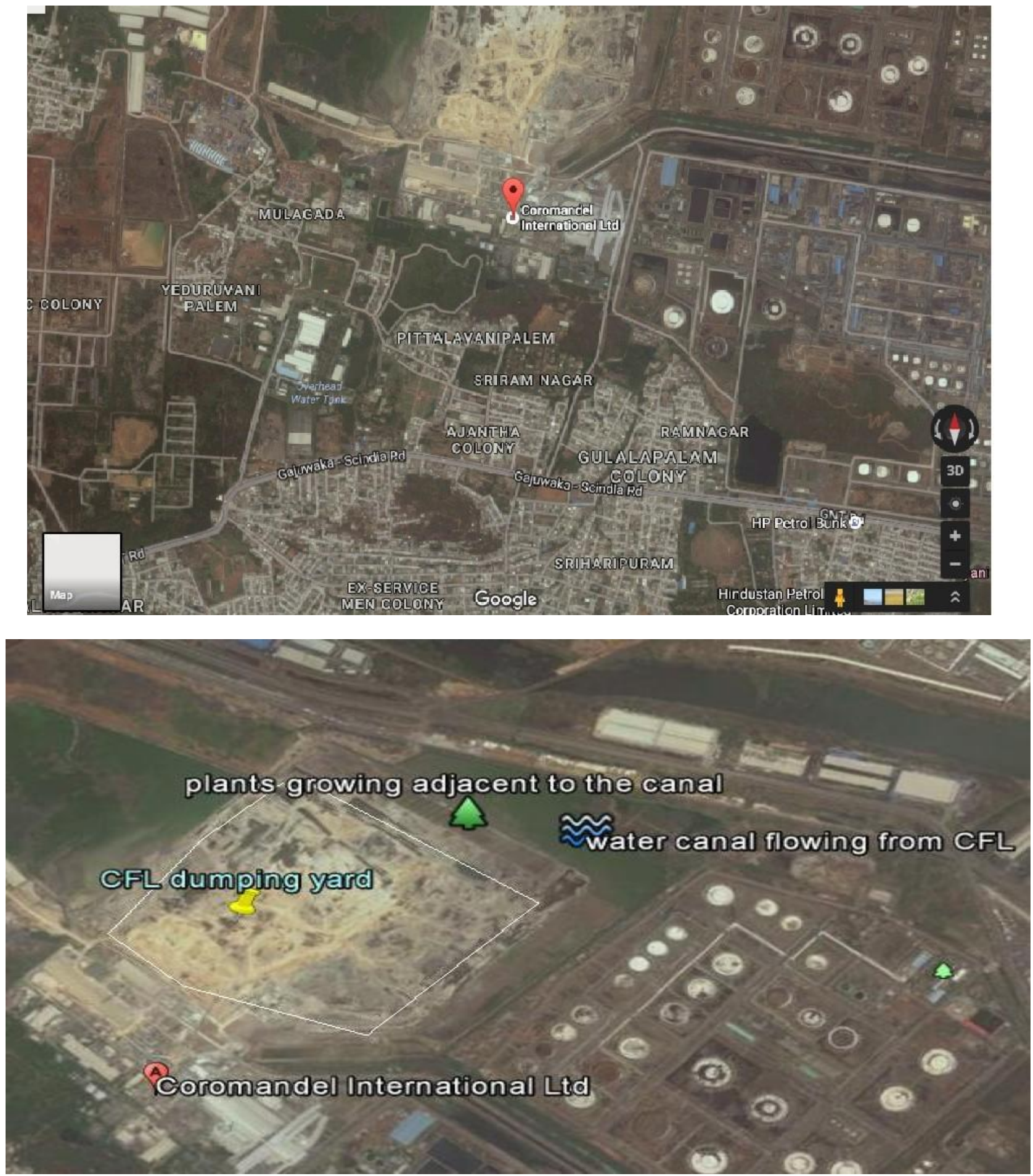

Fig:- 1, 2 Google maps showing the study area with location 

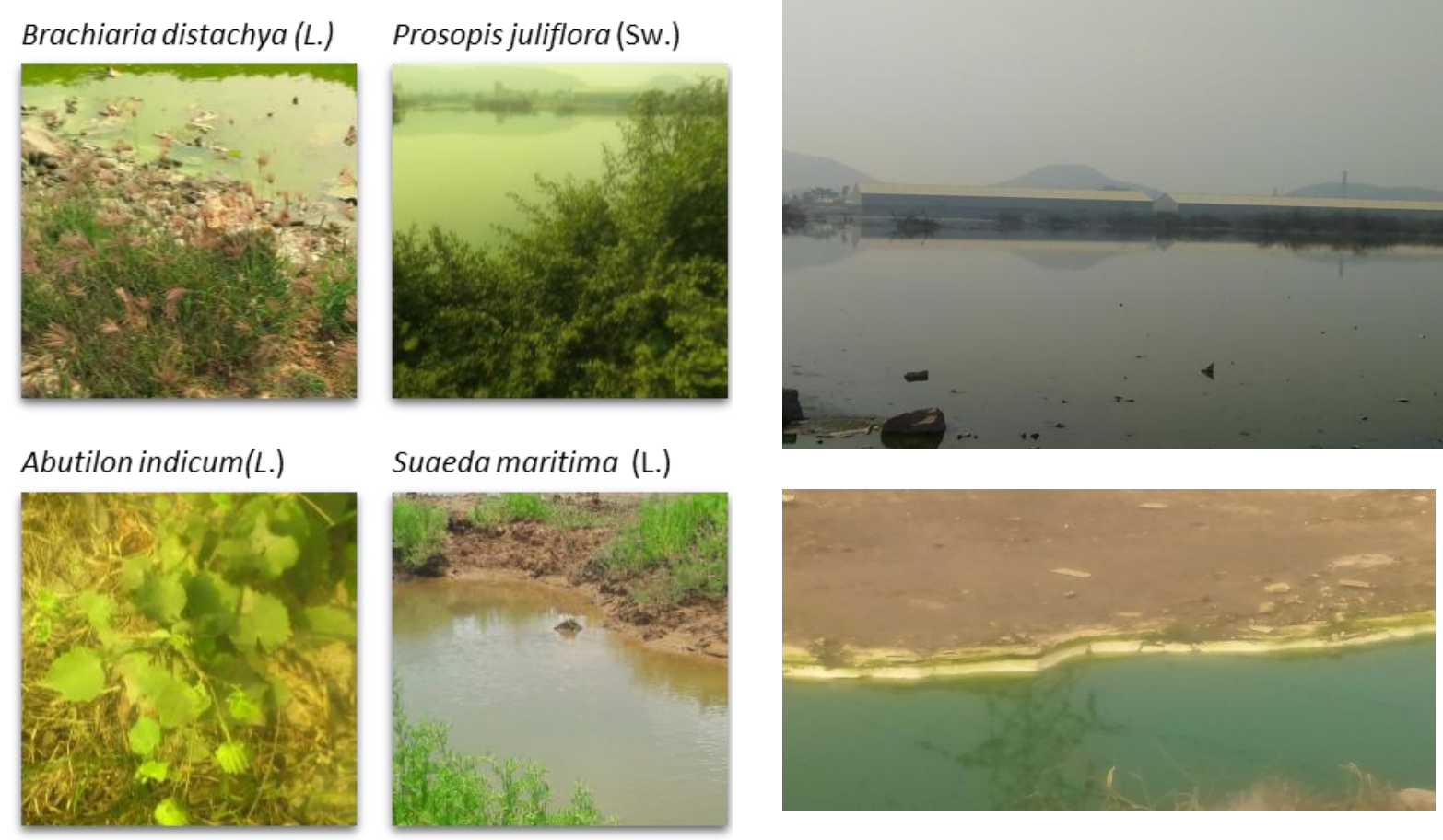

Fig3:photograph showing the plants growing and canal flow adjacent to the Fertilizer industry

\section{Materials and Methods:-}

The phyto diversity of an area adjacent to the Coromandel Fertilizer Limited that has high fluoride content was studied. The quadrats were laid $500 \mathrm{~m}$ apart $(10 \mathrm{~m} \mathrm{x} \mathrm{10m)} \mathrm{by} \mathrm{using} \mathrm{standard} \mathrm{quadrat} \mathrm{method} \mathrm{(Trivedi} \mathrm{and} \mathrm{Geol} \mathrm{1986).}$

The species available inside the quadrats were collected and identified with the help of floras namely Flora of The Presidency of Madras by Gamble (1915-1938), the Flora of The Presidency of Bombay by Cooke (1967) and Mangroves in India - Identification Manual by Banerjee et al. (1989) and other taxonomic literature. Quantitative characters like Abundance, Density, Frequency and their relative values and Importance Value Index (IVI) were calculated for each species by applying the following principles of Curtis and McIntosh(1950), Misra(1968) and Muller-Dombois and Eilenberg.(1974)

$$
\begin{aligned}
& \text { Frequency }(\%)=\text { Number of quadrats in which the species occurred x100 } \\
& \text { Total number of quadrats studied } \\
& \text { Density } \quad=\frac{\text { Total number of individuals of a species in all quadrats }}{\text { Total number of quadrats studied }} \\
& \text { Abundance } \quad=\text { Total number of individuals of a species in all quadrats } \\
& \text { Total number of quadrats in which the species occurred } \\
& \text { Relative density }(\mathrm{RD})=\frac{\text { density of individual species X } 100}{\text { Total Density of all species }} \\
& \text { Relative abundance }(\mathrm{RA})=\text { abundance of Individual species X } 100 \\
& \text { Total abundance of all species } \\
& \text { Relative frequency }(\mathrm{RF})=\underline{\text { frequency of individual species X100 }} \\
& \text { Frequency of all species }
\end{aligned}
$$




\section{IMPORTAT VLUE INDEX $=\mathrm{RA}+\mathrm{RD}+\mathrm{RF}$}

To determine the amount of total fluoride present in the plants whole plant were collected and washed with tap water several times and thoroughly washed with double distilled water to remove the dust on the surface of the plants. Samples were shade dried for twenty days and ground in a grain mill to fine powder, passed through a $50 \mathrm{~mm}$ mesh sieve. Samples were decomposed by alkaline carbonate fusion using $\mathrm{Na}_{2} \mathrm{CO}_{3}$ in platinum crucible at $450{ }^{\circ} \mathrm{C}$ for 12 hours. After extraction of the samples into $\mathrm{Na}_{2} \mathrm{CO}{ }_{3}$. The extract were acidified with dilute. $\mathrm{HCl}$ to $\mathrm{pH} 5.5$ and mixed with total ionic strength adjustment buffer (TISAB) to maintain the $\mathrm{pH}$ at 7.5 and the fluoride content determined by using fluoride ion selective electrode(ORION 4 star) (k. prabhavati devi,ch.sita Bindu et.al2016) the data is shown in table IV.

\section{Results and Discussion:-}

In the present investigation a total of 22 plant species were identified in the vast area of land present adjacent to Cormandal industry. Out of these 22 plant species 21 plants belonging to 12 families are dicots and 1 plant species of Poaceae is from monocots. The taxonomic position of plants and family wise percentage occurence of species are shown in table I and II. The details of phytosociological attributes of the identified species is shown in table III the IVI values are plotted in graph I. the amount of fluoride determined is presented in table IV.

Table I:- The taxonomic categories of plant species encountered in the study area

\begin{tabular}{|l|l|l|l|}
\hline Traditional plant group & Families & Genera & Species \\
\hline dicotyledons & & & \\
Polypetalae & 4 & 7 & 7 \\
Gamopetalae & 7 & 9 & 9 \\
Monochlamydae & 2 & 5 & 5 \\
\hline Monocotyledons & 1 & 1 & 1 \\
\hline Total & 14 & 22 & 22 \\
\hline
\end{tabular}


Table II:- Family wise percentage occurrence of plant species in the study area.

\begin{tabular}{|c|c|c|c|c|}
\hline S.No & Name of the family & $\begin{array}{c}\text { No. of } \\
\text { species }\end{array}$ & $\begin{array}{c}\text { No. of } \\
\text { genera }\end{array}$ & \% Species to the total species recorded \\
\hline 1 & Malvaceae & 1 & 1 & 4.545 \\
\hline 2 & Fabaceae & 4 & 4 & 18.18 \\
\hline 3 & Euphorbiaceae & 3 & 3 & 13.63 \\
\hline 4 & Acanthaceae & 1 & 1 & 4.545 \\
\hline 5 & Poaceae & 1 & 1 & 4.545 \\
\hline 6 & Apocyanaceae & 1 & 1 & 4.545 \\
\hline 7 & Solanaceae & 1 & 1 & 4.545 \\
\hline 8 & Convolvulaceae & 2 & 2 & 9.090 \\
\hline 19 & Cucurbitaceae & 1 & 1 & 4.545 \\
\hline 10 & Asteraceae & 2 & 2 & 9.090 \\
\hline 11 & Phyllanthaceae & 1 & 1 & 4.545 \\
\hline 12 & Plantaginaceae & 1 & 1 & 4.545 \\
\hline 13 & Cleomaceae & 1 & 1 & 4.545 \\
\hline 14 & Chenopodiaceae & 1 & 1 & 4.545 \\
\hline 15 & Amaranthaceae & 1 & 1 & 4.545 \\
\hline
\end{tabular}

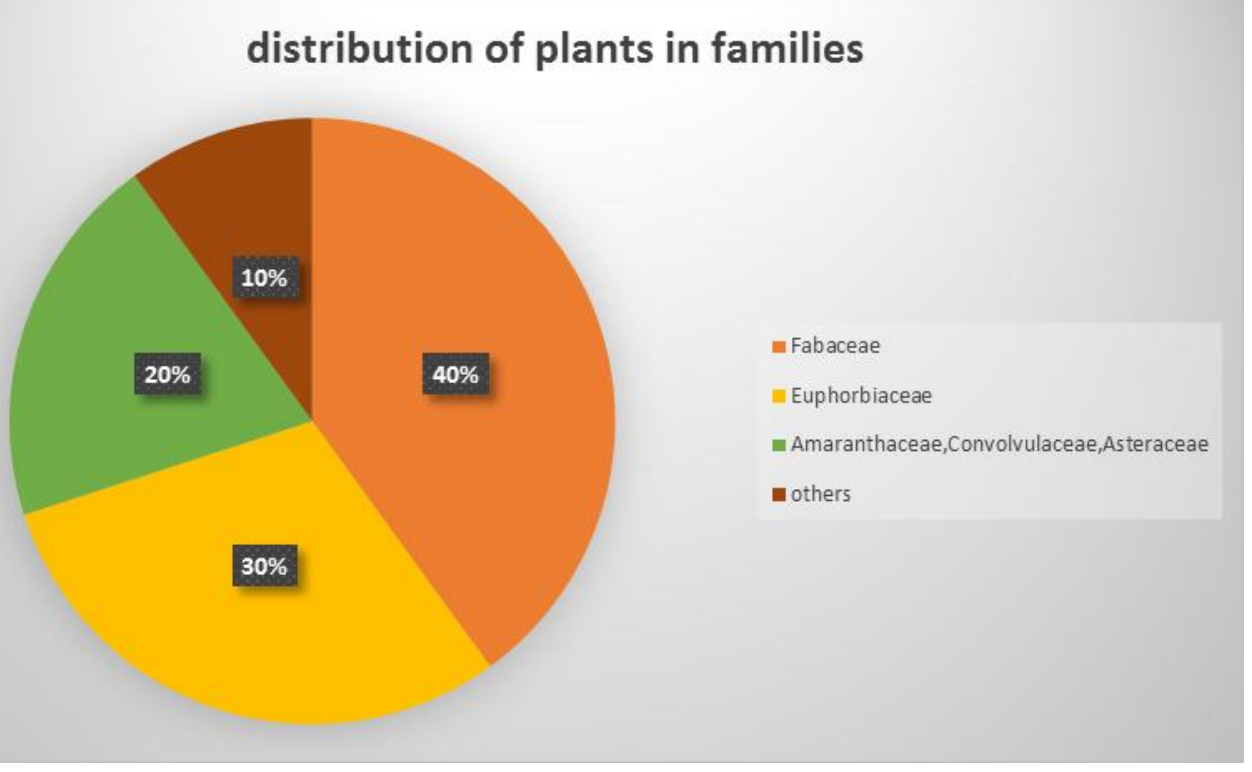

Table III:- Phytosociological Attributes of flora present in the study area.

\begin{tabular}{|c|c|c|c|c|c|c|c|c|c|c|}
\hline S No & Name of the species & TOI & TNI & A & $\mathrm{D}$ & $\mathrm{F}$ & RA & $\mathrm{RD}$ & $\mathrm{RF}$ & IVI \\
\hline 1 & Abutilon indicum (L.) & 6 & 57 & 9.5 & 5.7 & 0.6 & 0.061 & 0.119 & 0.091 & 0.271 \\
\hline 2 & Acacia Arabica $L$. & 2 & 25 & 12.5 & 2.5 & 0.2 & 0.081 & 0.052 & 0.03 & 0.163 \\
\hline 3 & Acalypha indica Linn. & 6 & 41 & 6.83 & 4.1 & 0.6 & 0.044 & 0.085 & 0.091 & 0.22 \\
\hline 4 & Amaranthus viridis $L$. & 2 & 21 & 5.25 & 2.1 & 0.4 & 0.034 & 0.043 & 0.061 & 0.138 \\
\hline 5 & Asystesia gangetica (L.) & 1 & 8 & 8 & 0.8 & 0.1 & 0.052 & 0.016 & 0.015 & 0.083 \\
\hline 6 & Brachiaria distachya $(L)$. & 3 & 47 & 15.6 & 4.7 & 0.3 & 0.101 & 0.098 & 0.046 & 0.245 \\
\hline 7 & Cassia occidentalis $L$. & 3 & 14 & 4.6 & 1.4 & 0.3 & 0.029 & 0.029 & 0.046 & 0.104 \\
\hline 8 & Calotropis gigantea (L.)R.Br. & 1 & 4 & 4 & 0.4 & 0.1 & 0.026 & 0.008 & 0.015 & 0.049 \\
\hline 9 & Cleome viscosa $L$. & 6 & 43 & 7.1 & 4.3 & 0.6 & 0.046 & 0.089 & 0.091 & 0.226 \\
\hline 10 & Clitoria ternate $L$. & 10 & 4 & 4 & 0.4 & 0.1 & 0.026 & 0.008 & 0.015 & 0.049 \\
\hline
\end{tabular}




\begin{tabular}{|l|l|l|r|r|r|r|r|r|r|l|}
\hline 11 & Datura ionoxa L. & 2 & 8 & 4 & 0.8 & 0.2 & 0.026 & 0.017 & 0.03 & 0.073 \\
\hline 12 & Euphorbia hirta L. & 7 & 31 & 4.42 & 3.1 & 0.7 & 0.029 & 0.065 & 0.106 & 0.2 \\
\hline 13 & Ipomea biloba L. & 2 & 31 & 15.5 & 3.1 & 0.2 & 0.099 & 0.065 & 0.03 & 0.194 \\
\hline 14 & Merremia tridentata L. & 1 & 3 & 3 & 0.3 & 0.1 & 0.019 & 0.006 & 0.015 & 0.04 \\
\hline 15 & Momordica charantia Roxb. & 2 & 4 & 2 & 0.4 & 0.2 & 0.013 & 0.008 & 0.03 & 0.051 \\
\hline 16 & Phyllanthus maderaspatensis L. & 2 & 7 & 8.5 & 1.7 & 0.2 & 0.055 & 0.036 & 0.03 & 0.121 \\
\hline 17 & Prosopis juliflora $($ Sw. $)$ & 2 & 12 & 6 & 1.2 & 0.2 & 0.039 & 0.025 & 0.03 & 0.094 \\
\hline 18 & Ricinus communis L. & 4 & 30 & 7.5 & 3 & 0.4 & 0.048 & 0.063 & 0.061 & 0.172 \\
\hline 19 & Suaeda maritima $($ L. $)$ & 5 & 27 & 5.4 & 2.7 & 0.5 & 0.035 & 0.057 & 0.075 & 0.167 \\
\hline 20 & Scoparia dulcis L. & 2 & 16 & 8 & 1.6 & 0.2 & 0.052 & 0.034 & 0.03 & 0.116 \\
\hline 21 & Tridax procumbens L. & 1 & 3 & 3 & 0.3 & 0.1 & 0.019 & 0.006 & 0.015 & 0.04 \\
\hline 22 & Vernonia Cinerea $($ L.)Less & 3 & 32 & 10.6 & 3.2 & 0.3 & 0.068 & 0.067 & 0.046 & 0.181 \\
\hline
\end{tabular}

TOI : Total Occurrence of Individuals. TNI: Total Number of Individuals A = Abundance, $\mathbf{D}=$ Density, $\mathbf{F}=$ Frequency $\mathbf{R A}=$ Relative Abundance $\mathbf{R D}=$ Relative Density $\quad \mathbf{R F}=$ Relative Frequency, $\mathbf{I V I}=$ Important Value

Graph I:- Showing the IVI variation of plants in the study area (Range of IVI variation (0.05 to 0.3 )

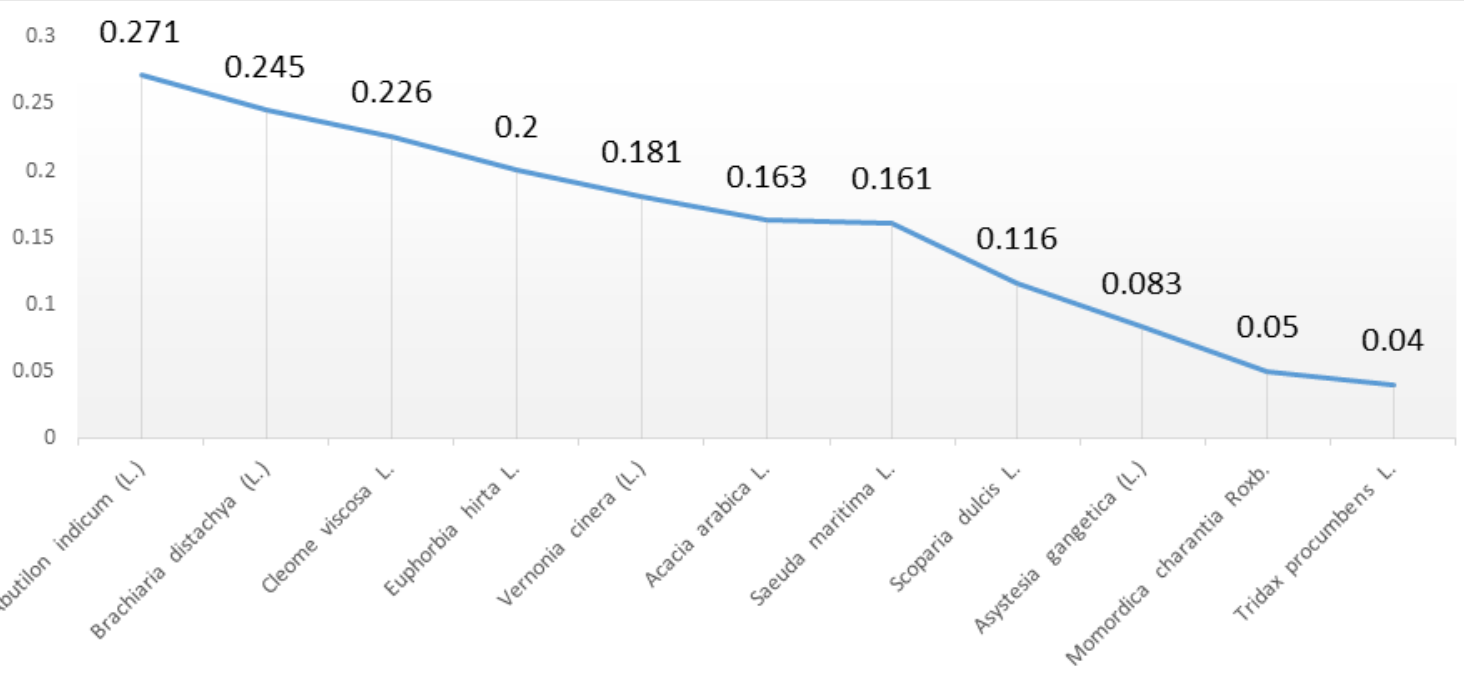

Table IV:- The determination of Fluoride present the plants.

\begin{tabular}{|l|l|l|}
\hline s.no & \multicolumn{1}{|c|}{ Name of the plants } & total amount of fluoride $(\mathrm{mg} / \mathrm{kg})$ \\
\hline $\mathbf{1}$ & Abutilon indicum $(L)$. & $\mathbf{4 . 8}$ \\
\hline 2. & Acalypha indica Linn. & $\mathbf{2 . 1}$ \\
\hline 3 & Acacia Arabica $L$. & $\mathbf{4 . 1}$ \\
\hline $\mathbf{4 .}$ & Amaranthus viridis $L$. & $\mathbf{3 . 1}$ \\
\hline $\mathbf{5 .}$ & Asystasia gigantica $(L)$. & $\mathbf{1 . 2}$ \\
\hline $\mathbf{6 .}$ & Brachiaria distachya $(L)$. & $\mathbf{2 7}$ \\
\hline 7 & Cassia occidentalis $L$. & $\mathbf{2 . 1}$ \\
\hline 8 & Cleome viscosa $L$. & $\mathbf{1 . 2}$ \\
\hline
\end{tabular}




\begin{tabular}{|l|l|l|}
\hline 9 & Clitoria ternata $L$. & $\mathbf{2 . 3}$ \\
\hline 10. & Euphorbia hirta $L$. & $\mathbf{4 . 2}$ \\
\hline 11 & Merremia tridentata Roxb. & $\mathbf{2 . 5}$ \\
\hline 12 & Prosopis juliflora & $\mathbf{5 7}$ \\
\hline 13. & Suaeda maritima $($ L. $)$ & $\mathbf{8 2}$ \\
\hline 14 & Scoparia dulcis $L$. & $\mathbf{3 7}$ \\
\hline
\end{tabular}

\section{Discussion:-}

The present study on the Taxonomic distribution of plants in families (table I) shows that majority of them belong to Gamopetalae i.e...7 families which include 9 genera and Polypetalae with 4 families which include 7 genera and only one from monocotyledonae. The percentage occurrence of species is highest in Fabaceae i.e...18.18 followed by Euphorbiaceae with 13.63 and the lowest number is seen in few families namely Malvaceae, Acanthaceae, Apocyanaceae, Cucurbitaceae with 4.54 (table II). The IVI values is highest for Abutilon indicum (L.) with 0.271 and second highest is Brachiaria distachya with 0.245 and least value in Tridax procumbens with 0.04. The Plants were examined for fluoride content and the results show highest accumulation in Suaeda maritima (L.) with $82 \mathrm{mg} / \mathrm{kg}$ and followed by Prosopis juliflora(Sw.) with $57 \mathrm{mg} / \mathrm{kg}$ and, Scoparia dulcis L. with $37 \mathrm{mg} / \mathrm{kg}$.

From the results it observed that the plants like Prosopis juliflora (Sw.), Scoparia dulcis L, Suaeda maritima (L.) are showing high amount of fluoride indicating their capacity to tolerate and grow which was supported by (Fatemeh et.al 2013). Further detailed study of plant, soil and microbe interactions is needed to affirm these plants as phytoremediants .

\section{Conclusion:-}

From the results it's proved that few plant communities are dominating even in the high Fluoride polluted area. So obviously, further detailed studies are needed to decide whether these species can be regarded as indicator species of fluoride pollution and the form of the fluoride stored is whether in elemental or free form in the plant. It is worthwhile to carry this kind of test to evaluate the variety of plant species so that it can serve the purpose of providing a green cover for industrial area.

\section{References:-}

1. Adams, d.f.1956. The effect of air pollution in plant life A.M.A. arch .Ind. health 14: 229-245.

2. Akbar KF, Ahmad Z, Shad MA, Ansari TM (2003). An Ecological study of roadside vegetation and soils in Sahiwal district. Online J. Biol.Sci. 3(7): 627-634

3. Al-Khashman OA (2007). Determination of metal accumulation in deposited street dusts in Amman, Jordan. Environ. Geochem. Health 29(1):1-10

4. Ares, J.O.Villa, G.Mandodari. Air pollutant uptake by xerophytic vegetation: fluoride Envior.exp.bot. 20:259269.

5. Thesis: Arjun Rao P.V, Studies on the genotoxic effects of the effluent from cormandal fertilizers limited 1992. M.Phil. thesis Visakhapatnam

6. Bonner, W. D., jun. \& Thimann, K. V. (1950). Amer. J. Bot. 37, 66.

7. Bindu Madhavi G. S. Bharathi and K. Gaurav Reddy Bioremediation and its applications. Journal of chemical and pharmaceutical sciences2014 .ISSN:0974-2115

8. Borjigin, S.; Ashimura, Y.; Yoshioka, T.; Mizuguchi, T.; Determination of Fluoride Using Ion selective Electrodes in the Presence of Aluminium. Anal.sci.2009, 25 (12), 1437-1443

9. Book: Curtis, J.T. \& R.P. McIntosh. 1950. The interrelationships of certain analytic and synthetic Phytosociological characters. Ecology 31: 434-455

10. Dueck, T.A and G.J.Endenjik. 1987. Soil pollution and changes in vegetation .chemosphere, 16:1021-1030

11. J.G. Ray and Jojo George, Phytosociology of road side communities to identify ecological potential of tolerant species. Journal of ecology and natural environment Vol.1 (5), pp184-190 November, 2009.

12. Jha SK, Nayek AK, Sharma YK (2009) Fluoride toxicity effects in onion (Allium cepa L.) grown in contaminated soils. Chemosphere, 76:353-356

13. Kabir M., M .zafir Iqbal, Z.R. Farooqi and M.Shafiq. Vegetation pattern and soil characteristics of the polluted industrial area of Karachi.Pak.J.Bot42 (1):661-67

14. K.P Sharma R.K. Chaturvedi ,kamayani Sharma and S.M.Bhardwaj dominance and diversity studies of vegetation of polluted habitats around sanganer, Jaipur. Tropical ecology 42(1):69-82, 2001. 
15. K. prabhavati Devi, Ch. Sri Bindu, T.byragi reddy,K, K. Basavaiah, and P. Vani. Accumulation of fluoride from soil by various plant species in the vicinity of fertilizer factory, Visakhapatnam . world journal of pharmacy and pharmaceutical sciences, volume 5, issue 9, 2122-2128

16. Krishna, M. V. B.; Rao, S. V.; Murthy, V. S. N.; Karunasagar, D.; A simple UV-photolysis digestion method for the determination of fluoride in fluorine-containing drugs by ion selective electrode and spectrophotometry techniques. Anal. Methods 2012, 4 (6), 1565-1572.

17. 17.Kumar, R.T., B.T. Reddy \& P.P. Murthy. 2013. Weed distribution in Sugarcane fields of Srikakulam district, A.P., India. Research Journal of Pharmaceutical, Biological and Chemical Sciences 4(1): 1380-1389.

18. Mc Nulty, I. B. \& Newman, D. W. (1957). Plant Physiology. 32, 121

19. McNulty, I. B. \& Newman, D. W. (1961). Plant Physiol. 36, 385.

20. 20.M. Gosh, SP. Singh (2005): A review on phyto remediation of heavy metals and utilization of it's by product. Appl.ecol.Environ.Res.3 (11-18)

21. 21.Book : Misra, R. 1968. Ecology workbook. Oxford and IBH publishing company Ltd., New Delhi.

22. Book: Muller - Dombois \& H. Eilenberg. 1974. Aims and Methods of Vegetation Ecology. John Wiley and Sons, New York.

23. Naheed, S.N. Arizd and S. Baig. Studies of particulate air pollutants in the vicinity of a cement factory and its health hazards. Pakistan journal of scientific and industrial research 29(4):95-102.

24. Fatemeh Kazemeini, Behroz Eshghi Malayeri Abdolkarim Chehregani, Bahare Lorestani, Ramezan Kalvandi Identification of the heavy metals accumulator plants in surrounding area of mine. International Journal of Agriculture and Crop Sciences. IJACS/2013/6-10/565-574

25. 25.Pragada, P.M. and M. Venkaiah. 2012. Phytosociological attributes of weed flora in major crops of north coastal Andhra Pradesh, India. Pakistan Journal of Weed Science 18(1): 107-126.

26. Syeda Sadaf jehra, Muhammad Arshad, Assement of heavy metal accumulation and their translocation in plant species. African journal of biotechnology vol.8 (12), pp.2802-.2810.

27. book : Thomas, M. D. \& Hendricks, R. H. (1956). In Air Pollution Handbook, sect. 9, p. 22. New York: McGraw-Hill Book Co.

28. Book : Trivedy RK, Goel PK (1986). Chemical and biological methods for water pollution studies.

Environmental Publications, India .Karad pp. $415-110$ 